Reprod. Nutr. Dévelop., 1982, 22 (3), 505-510.

\title{
Distribution of oxidases in the testis of buffalo, goat and ram : an histochemical study
}

\author{
G. S. BILASPURI (1), S. S. GURAYA
}

Department of Zoology

Punjab Agricultural University

Ludhiana, Punjab, India

\begin{abstract}
Summary. Peroxidase, monoamine oxidase (MAO) and cytochrome oxidase (CCO) have been histochemically localized in the testis of buffalo, goat and ram. The results in these three species were more or less similar. Peroxidase was localized only in the interstitial tissue and could be used as a marker enzyme for this testicular compartment. MAO and $\mathrm{CCO}$ were present in both the interstitial tissue and the seminiferous tubules. The detailed patterns of MAO and CCO distribution were also similar and showed cyclic changes in the spermatids which have not been reported before. The results have been compared and contrasted with those of previous workers and their possible physiological significance discussed.
\end{abstract}

\section{Introduction.}

The activity of monoamine oxidase (MAO) has been reported in the rat testis (Bhagvat et al., 1939 ; Zeller and Joel, 1941 ; Pentilla and Kormano, 1968), and Urry et al., (1972) demonstrated a simple microradiometric technique for the rapid measurement of MAO in that organ. Urry et al. (1975 a) studied the effect of age on testicular MAO in rat. MAO activity has also been studied in the squirrel (Frehn et al., 1973) and the Indian langur (Singh et al., 1974). Seasonal variations in the activity of this enzyme in the testis of the house sparrow and the squirrel have also been investigated (Urry et al., 1975 b). The distribution of peroxidase in the testis has been worked out only in the Indian langur (Singh et al., 1974). No attempt appears to have been made to study the distribution of testicular CCO in any species.

In spite of the great economic importance of farm animals, no work has been done on the distribution of their testicular oxidases. Furthermore, a knowledge of the basic machinery of cellular life is important. The present paper therefore reports the results of histochemical investigations of peroxidase, MAO and $\mathrm{CCO}$ in the normal mature testis of buffalo, goat and ram.

(1) Present address : Reproductive Biology Lab., Dept. of Biology, Guru Nanak Dev. University, Amritsar, Punjab, India. 


\section{Material and methods.}

Sexually mature male buffaloes (Bubalus bubalis), goats (Capra hircus) and rams (Ovis aries) were used for these investigations. The testicular material, taken from five buffaloes, nine goats and nine rams, was obtained from either whole testis or by biopsy. The enzymes were localized in $12-\mu$ thick sections of unfixed tissue cut with a cryostat maintained at $-20^{\circ} \mathrm{C}$. Peroxidase, MAO and CCO were localized using the methods of Van Duijn (improved diamino benzidine method), Glenner et al. (tetrazolium method) and Burstone, respectively, as cited in Pearse (1960). The sections were incubated at $37^{\circ} \mathrm{C}$ for $10 \mathrm{~min}, 40 \mathrm{~min}$ and $1 \mathrm{hr}$, respectively. Unstable blue crystals, blue formazan and reddish brown to blue-black colours indicated the presence of peroxidase, MAO and $\mathrm{CCO}$, respectively. The control sections for these enzymes were incubated with media lacking the substrates for the enzymes. The alternate sections were fixed in Bouin's fluid and used for easier routine hematoxylin staining, thus facilitating the correlation of MAO and $\mathrm{CCO}$ activity in the seminiferous tubule with the stages of the seminiferous epithelial cycle reported in the buffalo (Guraya and Bilaspuri, 1976), goat (Bilaspuri, 1978) and ram (Ortavant, 1958). The distribution and relative activity of the enzymes were studied on sections under lowpower and high-power microscopes.

\section{Results.}

The pattern of oxidase distribution was similar in the testis of buffalo, goat and ram. However, enzyme intensity in some testicular components showed species-specific variations (table 1).

Peroxidase. - The blue colour of the crystals produced by the activity of peroxidase disappeared after some time. Weak (goat and ram) to moderate (buffalo) activity was demonstrated in the interstitial tissue only (table 1); all other testicular cells reacted negatively to this enzyme.

MAO. - MAO activity was present in both the seminiferous tubules and the interstitial tissue (figs. 1-4) and appeared to be present in the mitochondria. The tubular wall also showed weak activity. Moderate activity was present in the interstitial tissue (table 1). Relatively high activity was demonstrated in the Sertoli cells (goat and ram) and the spermatogonia (buffalo and ram). The spermatocytes in the three species showed weak activity. Round spermatocytes showed moderate activity which increased in the elongating spermatids and elongated spermatids during the process of spermiogenesis (figs. $1-4 ;$ table 1 ). Activity in the sperm was weak in the post-nulear cap, whereas it was strong (buffalo and ram) to very strong (goat) in the mid-piece (table 1).

CCO. - CCO activity was demonstrated in both the interstitial tissue and the seminiferous tubules (fig. 5, table 1), and appeared to be present in the mitochondria. The distribution pattern of this activity was more or less similar to that of MAO. The interstitial tissue showed weak to moderate activity in buffalo and moderate activity in goat and ram. The activity in the Sertoli cells and 


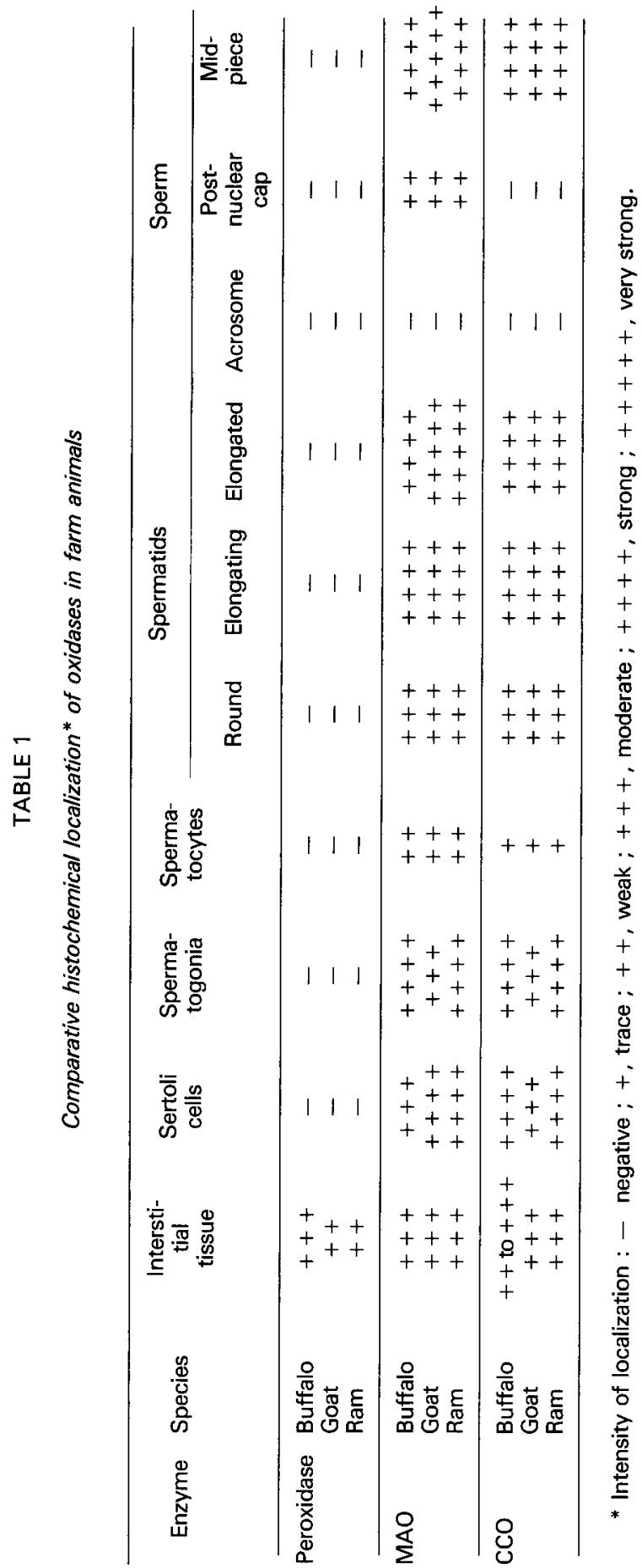



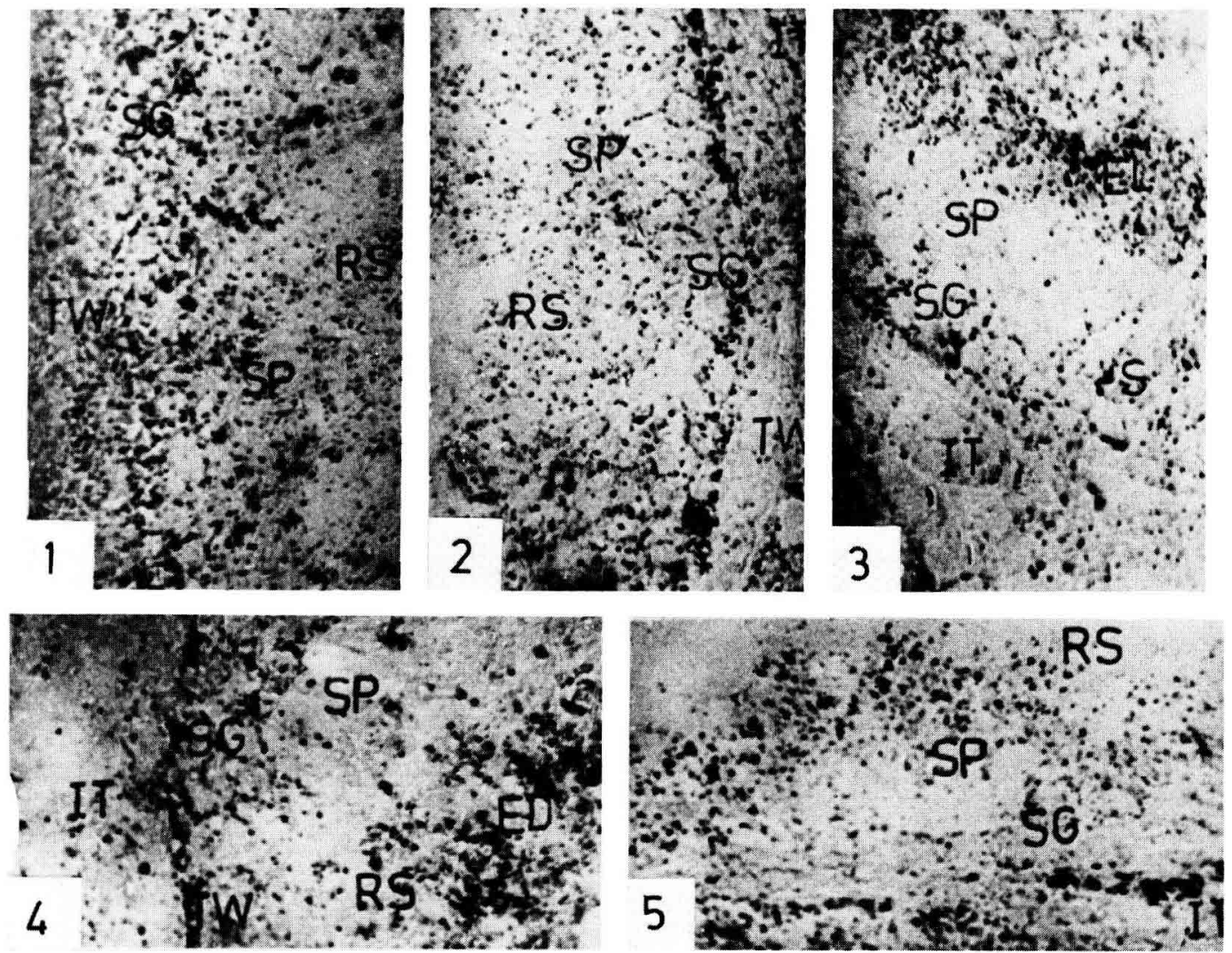

FIGS. 1 and 2. - Monoamine oxidase activity in stage 1 of buffalo and ram respectively $(\times 660)$.

FIG. 3. - Monoamine oxidase in stage 3 of ram $(\times 660)$.

FIG. 4. - Monoamine oxidase in stage 7 of goat $(x 660)$.

FIG. 5. - Cytochrome oxidase in the interstitial tissue and seminiferous tubule at stage 1 of ram $(\times 660)$.

Abbreviations : ED, elongated spermatids ; EL, elongating spermatids ; IT, interstitial tissue ; RS, round spermatids ; $S$, Sertoli cell ; SG, spermatogonia ; SP, spermatocytes ; ST, seminiferous tubule; TW, tubular wall.

spermatogonia was strong (buffalo and ram) to moderate (goat). Only trace activity was seen in the spermatocytes. The moderate activity in round spermatids increased in the elongating spermatids. Furthermore, the activity in the elongated spermatids was unaltered (table 1). Strong activity was observed in the sperm only in the mid-piece.

\section{Discussion.}

The results of the present studies on peroxidase are similar to those of Singh et al. (1974) who also reported its presence in the interstitial tissue of the 
Indian langur. Peroxidase may be involved in fatty acid oxidation, as suggested for the liver by Lehninger (1975). It was proposed that this enzyme might be used as a marker for the interstitial tissue to distinguish it from the seminiferous tubules of the testis.

The gross distribution of MAO activity in buffalo, goat and ram is similar to that reported by other workers (Bhagvat et al., 1939 ; Zeller and Joel, 1941 ; Pentilla and Kormano, 1968 ; Urry et al., 1972 ; Singh et al., 1974). MAO activity in the present species appears to be localized in the mitochondria of the seminiferous tubules and the Leydig cells, as also reported by Singh et al. (1974). The mitochondrial location of MAO has also been reported by Lehninger (1975), and MAO is used as a marker enzyme to indicate the presence of the outer membrane in the mitochondria. The results of the present studies differ from those of other workers on rat, which showed the main MAO activity to be in the walls of the seminiferous tubules (Urry et al., 1975 a) or in both the interstitial cells and the walls of the seminiferous tubules (Pentilla and Kormano, 1968). In farm animals, the main activity, found in the seminiferous tubules, showed cyclic changes in the spermatids which had not been reported previously.

MAO catalyzes the oxidation of various monoamines such as epinephrine (Lehninger, 1975). Urry et al. (1975 a) suggested that MAO may have a functional role in sexual development and tubular function. Working on the testis of the Uinta ground squirrel, Frehn et al. (1973) indicated that biogenic amines (whose metabolism is regulated by MAO activity) might act as mediators of stress and be responsible for the detrimental effects of stress on the male reproductive process. Similar MAO functions may also be expected in the present species.

So far, no histochemical or biochemical work appears to have been carried out on testicular $\mathrm{CCO}$; its distribution pattern in the present study is similar to that of MAO but its intensity is slightly less. Moreover, $\mathrm{CCO}$, in comparison to $\mathrm{MAO}$, is absent in the post-nuclear sperm cap. $\mathrm{CCO}$ is involved in electron transport chain and energy ATP production in the mitochondria (see Lehninger, 1975). The increase in MAO and CCO activity during spermiogenesis suggests a corresponding increase in metabolism and/or the concentration of mitochondria in a part (future mid-piece) of the developing and maturing spermatid.

Reçu en août 1981.

Accepté en décembre 1981.

Résumé. La localisation histochimique de la peroxidase, de la monoamine oxidase (MAO) et de la cytochrome oxidase (CCO) a été réalisée dans le testicule de buffle, de bouc et de bélier. Les résultats sont comparables dans les 3 espèces. La peroxidase, trouvée seulement dans le tissu interstitiel, pourrait être utilisée comme enzyme marqueur pour ce compartiment testiculaire. La MAO et la CCO sont présentes à la fois dans le tissu interstitiel et dans les tubes séminifères. La distribution de la MAO et de la CCO dans les cellules de la lignée germinale subit des modifications au cours du cycle spermatogénétique qui n'avaient pas été signalées auparavant. Les résultats sont en contradiction avec ceux obtenus antérieurement; leur signification physiologique est discutée. 


\section{References}

BILASPURI G. S., 1978. Morphological, histochemical and biochemical studies on the testes of some farm animals. Ph. D. Thesis, Punjab agric. Univ., Ludhiana, India.

BHAGVAT K., BLASCHKO H., RICHTER D., 1939, Amine oxidase. J. Biochem., 33, 1338.

FREHN J. L., URRY R. L., BALPH D. F., ELLIS L., 1973. Photoperiod and crowding effects on testicular serotonin metabolism and lack of effects on melatonin synthesis in Uinta ground squirrel's (Spermophilus armatus). J. exp. Zool., 183, 139-144.

GURAYA S. S., BILASPURI G. S., 1976. Stages of seminiferous epithelial cycle and relative duration of spermatogenic processes in buffalo. Morph. $J b$., 122, 147-161.

LEHNINGER A. L., 1975. Biochemistry. The molecular basis of cell structure and function. Worth Publ. Inc., New York.

ORTAVANT R., 1958. Le cycle spermatogénétique chez le Bélier. D. Sci. Thesis, Univ. Paris, Paris.

PEARSE A. G. E., 1960. Histochemistry : theoretical and applied. 2nd Ed., J. A. Churchill, London.

PENTILLA A., KORMANO M., 1968. Monoamine oxidase activity in the testis and epididymis of rat. Ann. Med. exp. Biol. Fenn., 46, 557-563.

SINGH K., KAUL D. K., MATHUR R. S., 1974. Histochemical demonstration of certain testicular enzymes of the Indian langur. Acta anat., 90, 300-309.

URRY R. L., JAUSSI A. W., ELLIS L. C., 1972. Simple microradiometric technique for the rapid measurement of monoamine oxidase activity in rat testicular minced and teased-tubular preparation. Analyt. Biochem., 50, 549-557.

URRY R. L., DOUGHERTY K. A., ELLIS L. C., 1975 a. Alternations with age in rat seminiferous tubule monoamine oxidase activity when compared with whole testicular tissue. Proc. Soc. exp. Biol. Med., 148, 805-837.

URRY R. L., FREHN J. L., DIXON K. L., BALPH D. F., ELLIS C., 1975 b. Seasonal variations in testicular monoamine oxidase in house sparrow (Passer domesticus) and Uinta ground squirrels (Spermophilus armatus). Experientia, 31, 273-274.

ZELLER E. A., JOEL C. A., 1941. Amine oxidase and its location. Helv, chim. Acta, 24, 968. 